\title{
Strategies for developing knowledge economy in Romania
}

\author{
Shahrazad HADAD \\ The Bucharest University of Economic Studies, Bucharest, Romania \\ Academy of Romanian Scientists, Bucharest, Romania \\ shahrazad.hadad@fabiz.ase.ro
}

\begin{abstract}
The present paper delves into the specifics of knowledge economy with a particular focus on Romania. In the first part, it identifies knowledge economy characteristics and pillars and it analyses them as compared to levels exhibited by countries in the European Union. In the second part it argues for the strategies that could be used for enhancing knowledge economy in Romania. In order to do so we used the Delphi method and we identified 25 experts in the knowledge economy/management field coming from internationally renowned companies, universities and ministries located in Romania, to whom we sent invitations for participating in our Delphi survey that lasted one month. Out of the 25 experts, 10 answered positively and during the research we had an attrition rate of $90 \%$. The experts delivered their opinions on the measures to be adopted in order to increase education and learning, ICT and innovation as building blocks of knowledge economy. Findings reveals that knowledge economy can be developed by adopting measures such as: devising a governmental program that will sustain the development of knowledge repositories at the level of technological clusters, industry associations and other professional organizations by providing financial assistance for hardware acquisition and software development in order to facilitate knowledge transfer; Governmental program for the financial support of schools' investments in hardware and educational software and the training of staff for the use of ITC in teaching and learning, etc.
\end{abstract}

Keywords: knowledge economy, knowledge management, strategies, knowledge economy strategies, strategic management.

Please cite this paper as follows: Hadad, S. (2017), "Strategies for developing knowledge economy in Romania", Management \& Marketing, Challenges for the Knowledge Society, Vol. 12, No. 3, pp. 416-430. DOI: 10.1515/mmcks-2017-0025.

\section{Introduction and brief literature review}

The present paper is built based on the paper "Knowledge economy: characteristics and dimensions" by Hadad (2017) therefore most of the definitions and findings will not be reiterated, but only mentioned or referred to.

Knowledge is one of the most important strategic resources held by individuals, companies and states as it renders competitiveness and it ensures a strategic place on the market (Bolisani and Bratianu, 2017; Bratianu, 2013). As it is an intangible asset, the use and sharing of knowledge will generate new knowledge. An important aspect that companies need to account for nowadays is related to employing all sorts of knowledge generation strategies. According to Bratianu and Bolisani (2015) there are four major strategies for generating knowledge based on the known-unknown matrix: exploitation strategies, acquisition strategies, sharing strategies and exploration (knowledge creation) strategies. Now, these strategies can be adopted by companies based on the industry that they belong to, based on the company cycle and actually based on the wants and need of the companies. But these strategies cannot be adopted generically at a national level if a particular state or country wants to improve, for example, its knowledge economy.

Knowledge economy is becoming mainstream in terms of strategic orientation as shown by Europe 2020 strategy which was designed to create knowledge economies all 
across Europe (Fucec, 2015), and its importance is highlighted by the fact that OECD (1996) regards knowledge economy as tied up to high skills-performance-value scenarios which become an imperative weapon for both countries and companies to be able to face the global competition.

In the new setting, we are witnessing a shift from traditional production factors such as land, labour and capital to a new vision based on innovative production of knowledge and intellectual capital (Bratianu, 2011; European Commission, 2014). For ensuring the success of the shift, it must be complemented by the creation of a new institutional system centred on research and development units intended to link multifunctional and disciplinary institutions into clusters and strategic alliances. The emergence of new types of institutions is therefore inevitable and necessary: the knowledge creation company (Nonaka and Takeuchi, 1995) and there are: exclusively knowledge exporter companies (research institutes, consulting firms, etc.); knowledge exporter companies, but which also use knowledge internally (large companies that have own research units or even some cognitive-intensive SMEs such as software producers; some laboratories or incubators); knowledge importer organisations (hightech companies that assimilate knowledge and advanced technologies, hospitals, etc.); autarchic organisations (are those that create knowledge only for their own use like traditional enterprises that solve standardised production problems and product life cycle); and routine organisations (that undertake activities that do not require the creation of knew knowledge such as arts and crafts SMEs - especially in the villages of our country) (Hoffman and Glodeanu, 2005).

We set as starting point the definition of knowledge economy as being reflected by "economies which are directly based on the production, distribution, and use of knowledge and information" (OECD, 1996, p. 7). The dominant features of knowledge economy are open innovation, education, knowledge management and creativity that are grounded in ICT and the existence of highly trained and well educated workers. Knowledge-intensive sectors such as IT, healthcare and software are dominated by knowledge as core competence and competitive advantage (Bolisani and Bratianu, 2017, Fonseca and Domingues, 2017). Organizations should develop a new type of leadership and organizational culture, and become intelligent and learning organizations (Bratianu and Anagnoste, 2011; Bratianu et al., 2011; Ghinea and Bratianu, 2012). A special role may have universities in generating new knowledge and developing new ways of thinking in concordance with the intangible nature of knowledge (Bejinaru, 2017; Bratianu and Vasilache, 2010; Nonaka and Takeuchi, 1995).

The four pillars of knowledge economy are: education, innovation, ICT and learning. The efforts of the World Bank have their pinnacle in 2012 when the WB managed to deliver enough data for measuring KE in accordance with its four pillars (the data presented is gathered within the period 1995-2012, and new additions will be brought by the end of December 2017). The profile of knowledge economy is Romania is accurately depicted by Figure which presents the evolution of the Knowledge Index, Knowledge Economy Index, Innovation Index, Education Index, ICT Index, and EIR Index. All these indexes have undergone an improvement throughout the year's stating 1995 and ending 2012 


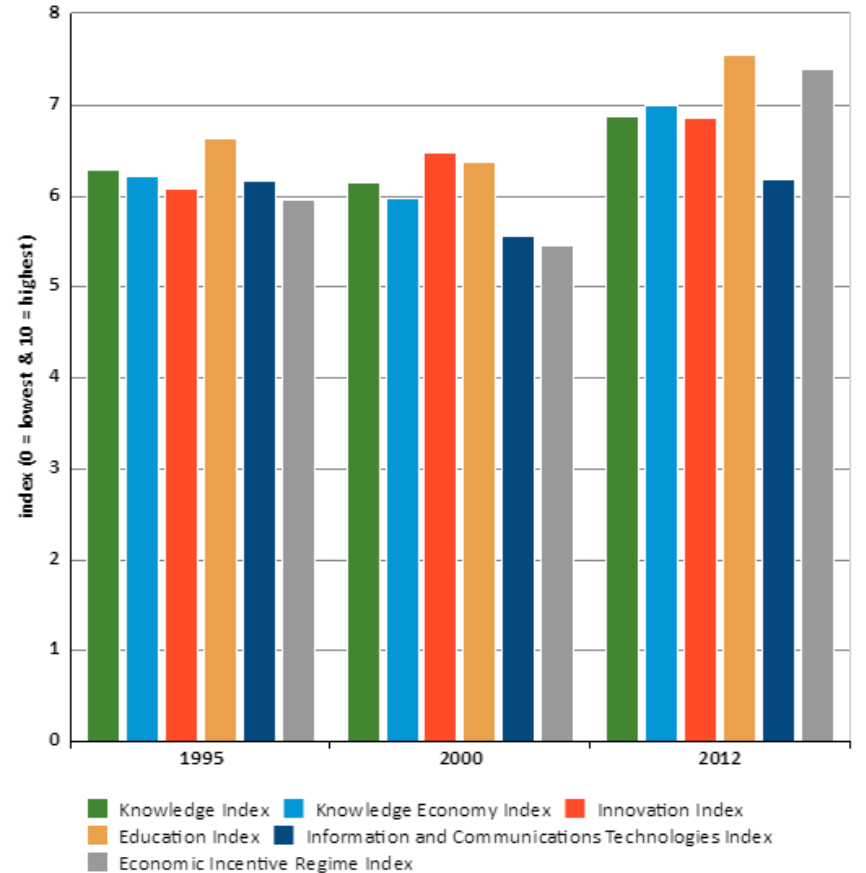

Figure 1. Knowledge economy in Romania 1995-2012

Source: World Bank.

Knowledge Economy Index (KEI) is an aggregate index representing a country's or region's general development level of the knowledge-based economy or the overall preparedness to compete in the Knowledge Economy (KE) and it is based on a simple arithmetic mean of four subindexes, which represent the four pillars of the knowledge economy: Economic Incentive and Institutional Regime (EIR); Innovation and Technological Adoption; Education and Training; Information and Communications Technologies (ICT) Infrastructure (Chen and Dahlman, 2005; World Bank, 2009, 2012) and they are depicted in Figure 1. The arithmetic mean of Education Index, Innovation Index and ICT Index form together the Knowledge Index (KI) - which is the second global index that assesses the knowledge potential of a country. According to the World Bank, these indexes range between 0 and 10, where 10 is the highest value representing the best case scenario.

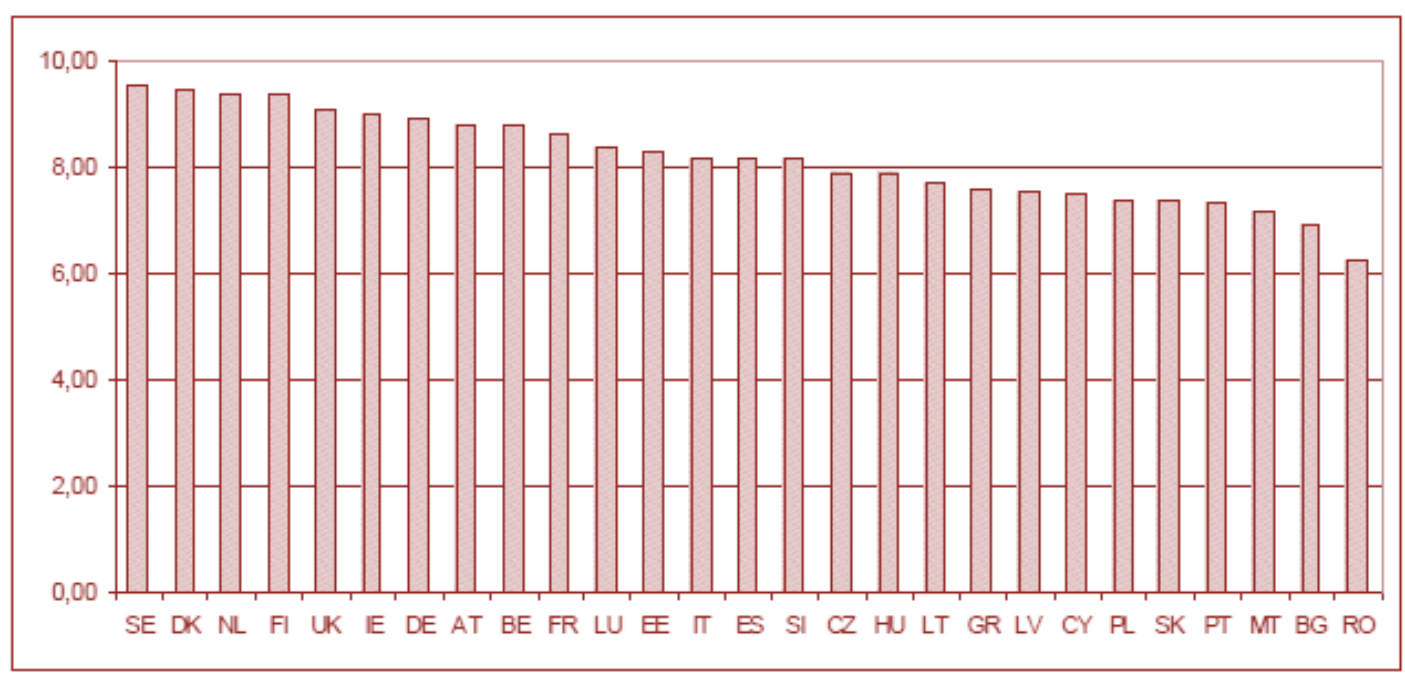

Figure 2. Knowledge economy index Europe, 2009 
In a geographic study conducted by Skrodzka (2016), in the 2000s Romania was found next to Greece, Portugal and Bulgaria as lagging in terms of knowledge-based economy (KBE) development, additionally in 2013, Romania was still characterised by a very low level of KBE development, alongside Greece and Bulgaria. Moreover, the research revealed a positive influence of knowledge economy pillars on the knowledge economy development of the countries, alongside the strong positive relationship between knowledge economy development and the economic development level.

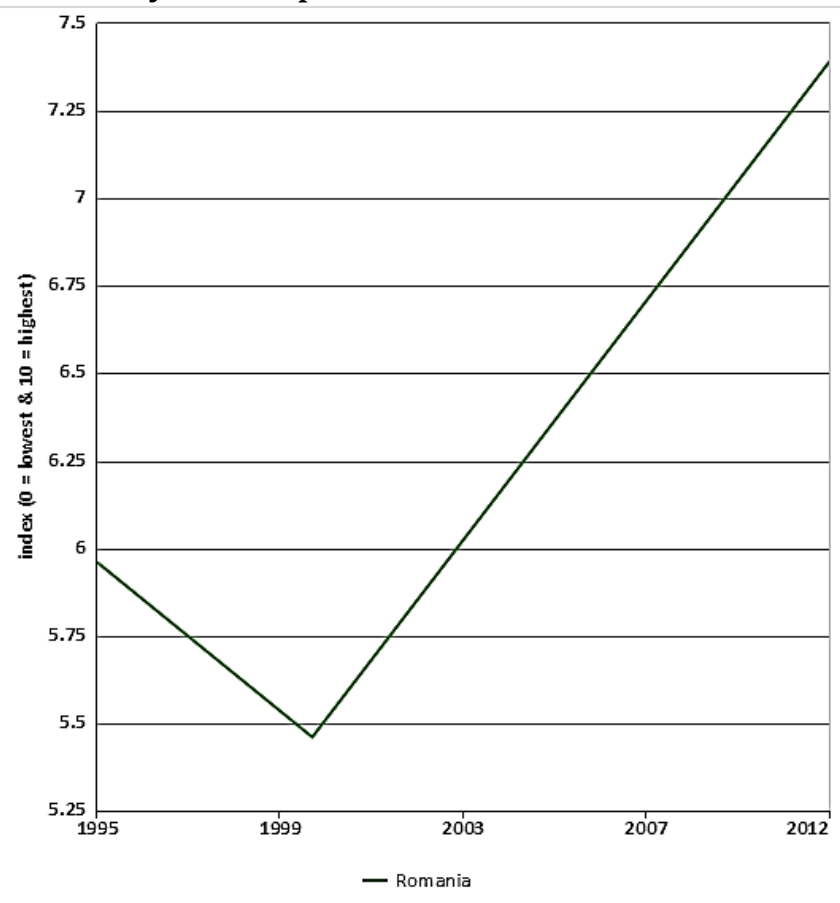

Figure 3. Economic Incentive and Institutional Regime (EIR) in Romania 1995-2012

Source: World Bank.

Since last decades have witnessed the steadily growing role of knowledge in the creation of economic wealth (Brinkley 2006), KE has become an important index for measuring and comparing economies, in EU as well as in Romania (Herciu and Ogrean, 2011; Ogrean et al., 2010; Popa, 2013). Needless to say, in well-developed economies, knowledge can be seen as even more critical, as the inner, rather invisible engine boosting economic development (Veugelers and Mrak, 2009). Figure... presents the EIR index which reflects incentives that promote the efficient use of existing and new knowledge and the flourishing of entrepreneurship which is ensured by tariff and nontariff barriers, the regulatory quality and "enhancement and stimulation of knowledge creation, dissemination and utilization" (Đonlagić et al., 2015, p. 259) supported by an adequate division of resources. 


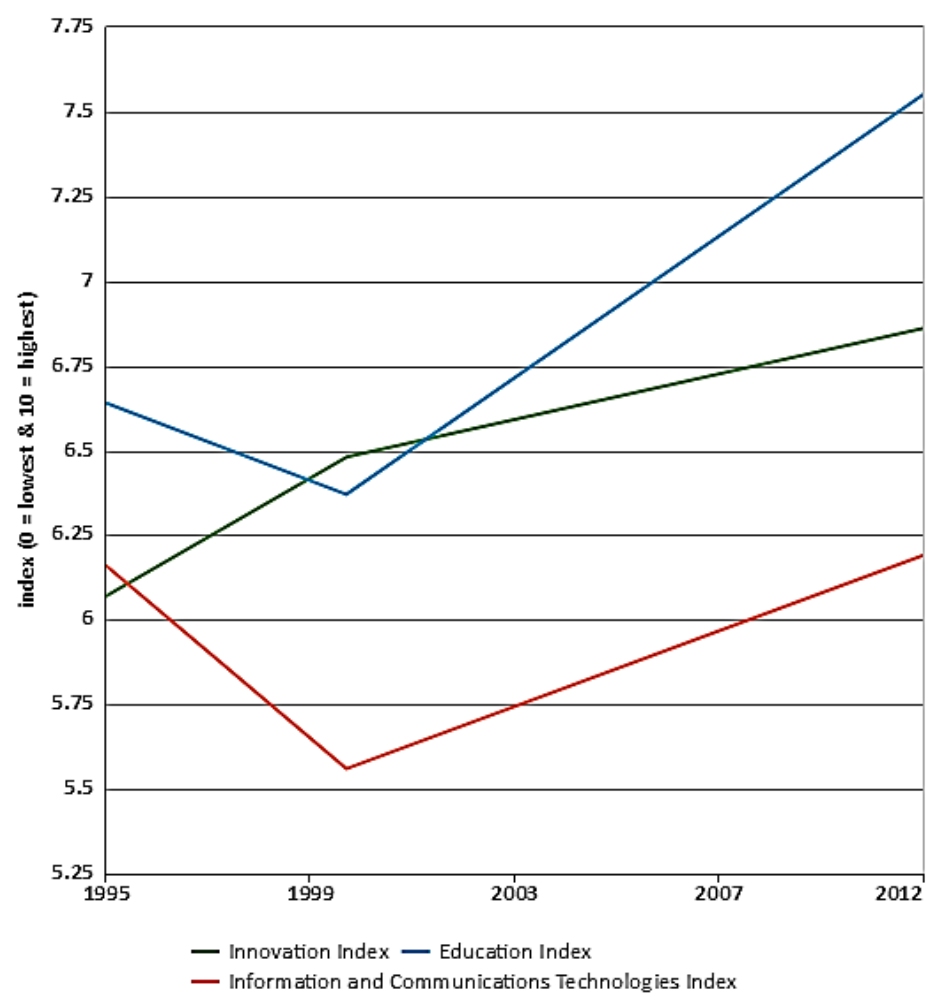

Figure 4. Innovation, Education and ICT Indexes in Romania 1995-2012

Source: World Bank.

ICT peaked in 1995 and it went downward slopping until 2000 when it registered its minimum when Romania was tormented by slow economic reforms, new leadership, strikes and poverty (Fredom House, 2001) and ever since it has been improving but it is one of the least values of the KE pillars. The same trends can be observed in education, whereas Innovation incurred a continuously positive evolution.

\section{Research methodology}

The objective of the present research is to establish the best public measures to be taken in order to improve the knowledge economy subindexes at which Romania performs poorly. Therefore we used three research methods.

In the first part of the paper we conducted literature review and exploratory analysis to identify the key components of knowledge economy. In order to do so, we based our research on Hadad (2017) who analysed the most important studies and articles published in periodicals that cover topics such as economics, business, and management. Another source of information was represented by the World Bank which is the main authority in terms of knowledge economy. The articles were identified based on the presence of keywords in their title, abstract and body.

Next, we used Analytic Hierarchy Process to establish the areas in which Romania underscores with respect to knowledge economy, by using both secondary sources of data (World Bank) and primary sources of data (delivered by the experts) and we validated the results by computing Saaty Compatibility Index.

After having established the areas which need improvement we proceeded with the Delphi method to find out which strategies should be employed to improve overall knowledge economy in Romania. We resorted to Delphi method since the opinion of a group of experts is more useful than the opinions of individuals and the consensus reached within a group is less prone to subjectivity as would be the case of individual 
experts' opinions (Murry and Hammons, 1995). Moreover, we are advocating for the method of experts because they are holders of asymmetric and timely information as compared to scientific literature (Lang, 1994). Delphi consists in establishing an objective to be investigated, creating a questionnaire to assess the experts' opinion, finding a moderator, identifying the experts, conducting two or three iterations of consultations, data aggregation and feedback, results analysis and reporting (Franklin and Hart, 2007). Concerning the sources of data, the experts have to be knowledgeable and their number varies between 7 to around 20 (Gordon, n.d.). We followed the classic design of the Delphi method (Hsu and Sandford, 2007).

\section{Research results and analysis}

To test the reliability and anchoring on the market and economic reality of the experts we have resorted to Analytic Hierarchy Process (as explained by Hadad, 2015; Saaty, 2008) in which we asked the 9 experts to rank in terms of importance the components of knowledge economy - their ranking would be an indication of the KEI component that needs better policies. The process implied the pairwise comparison of the indexes followed by the computation of the priority vectors for each expert, followed by the calculation of group priority vector using the geometric mean. The true priority vectors were computed based on the available data from the World Bank website. The final step was to calculate the compatibility index between the aggregated priority vectors and the true priority vectors.

In order to deliver the true priority vectors for the KE indexes we averaged the corresponding indexes as shown in Table 1:

Table 1. Averages for KEI components

\begin{tabular}{|l|l|l|l|l|}
\hline Index & $\mathbf{1 9 9 5}$ & $\mathbf{2 0 0 0}$ & $\mathbf{2 0 1 2}$ & Average \\
\hline EIR & 5.96 & 5.46 & 7.39 & 6.27 \\
\hline Innovation & 6.07 & 6.48 & 6.86 & 6.47 \\
\hline Education & 6.64 & 6.37 & 7.55 & 6.85 \\
\hline ICT & 6.16 & 5.56 & 6.19 & 5.97 \\
\hline KEI & 6.21 & 5.97 & 7.00 & 6.39 \\
\hline
\end{tabular}

Source: Author's own processing.

Table 2. True Priority Vectors for KEI components

\begin{tabular}{|l|l|l|}
\hline Index & Average & $\begin{array}{l}\text { True Priority } \\
\text { Vector (TPV) }\end{array}$ \\
\hline EIR & 6.27 & 0.245305164 \\
\hline Innovation & 6.47 & 0.25312989 \\
\hline Education & 6.85 & 0.268127282 \\
\hline ICT & 5.97 & 0.233568075 \\
\hline TOTAL & 25.56 & - \\
\hline
\end{tabular}

Source: Author's own processing.

The TPVs reveal the fact that Romania underscores in Information and Communication Technologies, while having a better score for Education, therefore the debate of the experts should revolve around finding strategies to improve ICT, followed by EIR, Innovation and Education to ultimately ensure the development of knowledge economy in Romania.

After the pairwise comparison of the indexes, we created, in the SuperDecisions software, a four-by-four consistent matrix (below 0.01) for each expert and then we aggregated the results by using the geometric mean (Table 3) which is specific for small 
group decisions and with no effects on the representativeness of the sample (Hadad, 2015).

Table 3. Actual geometric mean results with respect to KEI components

\begin{tabular}{|l|l|}
\hline KEI & PV \\
\hline EIR & 0.25 \\
\hline Innovation & 0.28 \\
\hline Education & 0.27 \\
\hline ICT & 0.2 \\
\hline
\end{tabular}

Source: Author's own processing.

The compatibility index between the True Priority Vectors and the results obtained in SuperDecisions was obtained by "multiplying elementwise the matrix of pairwise ratios of the model estimate data, by the transpose of the matrix of pairwise ratios of the actual normalized data, adding all the resulting entries and dividing" (Whitaker, 2007, p. 850) it by the square of the matrix rank:

Table 4. Pairwise comparison matrix from actual data - $X$

\begin{tabular}{|l|r|r|r|l|}
\hline \multicolumn{1}{|c|}{ X } & \multicolumn{1}{|l|}{ A1 } & \multicolumn{1}{l|}{ A2 } & \multicolumn{1}{l|}{ A3 } & A4 \\
\hline A1 & 1 & 0.96909 & 0.91533 & 1.050251 \\
\hline A2 & 1.0318979 & 1 & 0.94453 & 1.083752 \\
\hline A3 & 1.092504 & 1.05873 & 1 & 1.147404 \\
\hline A4 & 0.9521531 & 0.9227202 & 0.87153 & 1 \\
\hline
\end{tabular}

Source: Author's own processing.

Table 5. Transpose of pairwise comparison matrix from estimated data - $X^{T}$

\begin{tabular}{|l|r|r|r|r|}
\hline \multicolumn{1}{|c|}{$\mathbf{X}^{\mathbf{T}}$} & \multicolumn{1}{l|}{ A1 } & \multicolumn{1}{l|}{ A2 } & \multicolumn{1}{l|}{ A3 } & A4 \\
\hline A1 & 1 & 1.03571 & 0.64286 & 0.85714 \\
\hline A2 & 0.9655172 & 1 & 0.62069 & 0.82759 \\
\hline A3 & 1.5555556 & 1.61111 & 1 & 1.33333 \\
\hline A4 & 1.1666667 & 1.20833 & 0.75000 & 1 \\
\hline
\end{tabular}

Source: Author's own processing.

Table 6. Result of Hadamard (cell-wise) multiplication of the two matrices [ $\left.H=X^{*} X^{T}\right]$

\begin{tabular}{|l|r|r|r|r|}
\hline \multicolumn{1}{|c|}{ H } & \multicolumn{1}{l|}{ A1 } & \multicolumn{1}{l|}{ A2 } & A3 & A4 \\
\hline A1 & 1 & 1.0036984 & 0.58843 & 0.90022 \\
\hline A2 & 0.99632 & 1 & 0.58626 & 0.89690 \\
\hline A3 & 1.69945 & 1.70574 & 1 & 1.529872 \\
\hline A4 & 1.11085 & 1.11495 & 0.653649635 & 1 \\
\hline
\end{tabular}

Source: Author's own processing.

Compatibility Index $=\frac{\text { cell } \sum H}{n^{2}}, \mathrm{n}=$ rank of the matrix

$$
\text { Compatibility Index }=\frac{16.786316618404}{4^{2}}=1.04914478865025
$$

The value of the Compatibility Index is 1.049144789 which is very good (Whitaker, 2007) and it was calculated to establish the closeness between the actual data available from the World Bank and the results delivered from the group of experts, consequently $\mathrm{CI}$ indicates that the experts are up-to-date concerning knowledge economy and their opinions can be used for further research. The results were not shared with the experts, they were kept secret and they were to be shared with them at the end of the Delphi research. 
After establishing the reliability of the judgments of the experts, we proceeded to the second part of our research. The main objective of the Delphi method was to identify potential public policies for enhancing the effectiveness of knowledge economy. The subobjectives were:

1. Identify public policies for education and learning,

2. Identify public policies for innovation,

3. Identify public policies for EIR,

4. Identify public policies for ICT.

The sampling of the experts was done based on a multidisciplinary criterion stemming from the background of the participants and the fields from which they came. We have identified 25 experts in the knowledge economy/management field coming from internationally renowned companies, universities and ministries located in Romania, to whom we sent invitations for participating in our Delphi survey that lasted one month. Out of the 25 experts, 10 answered positively, and during the research we had an attrition rate of $90 \%$. The selected companies are dispersed across Romania and they represent producers, suppliers and consultants in different industries (IT, automotive, outsourcing, etc.). We chose to focus on Romania for it is one of the laggards of Europe and our action was consistent with the principle according to which the velocity of the group is given by the velocity of the slowest in the group. The experts volunteered and identified themselves to the group via an online form. With respect to descriptive nature of the study, the experts provided their position, experience (seniority) and age:

\section{Distribution of experts}

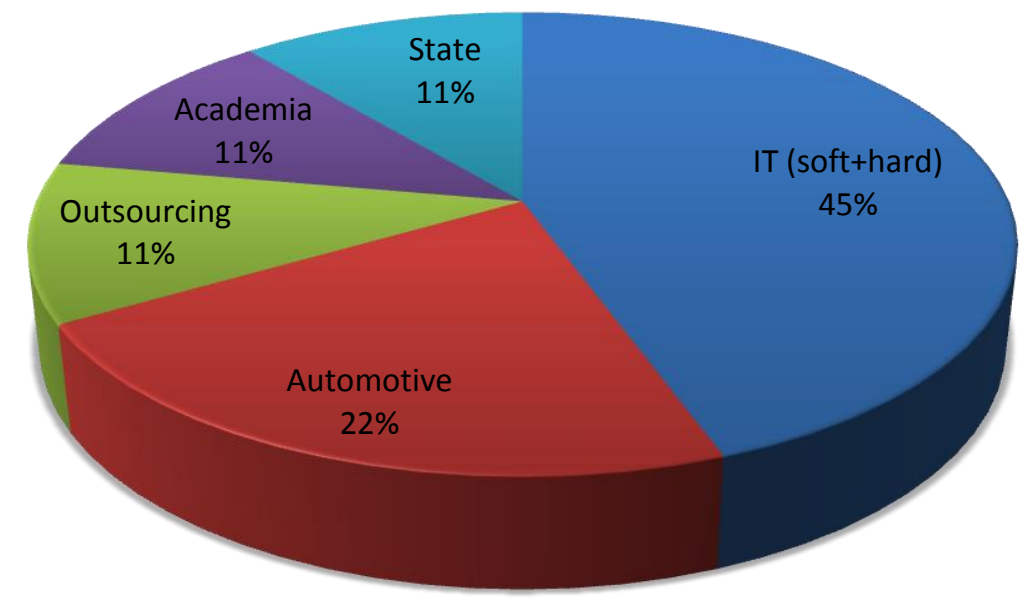

Figure 5. Domain distribution of experts

Source: Author's own processing.

The data was collected following the recommended procedures for Delphi. The initial questioning also contained open questions and in the final round the respondents were presented with closed questions built based on the previous round, and they had to choose the two most important pillars of knowledge economy that needed public 
support. After two rounds of questionnaires, the experts have agreed upon the following strategies to be taken for developing knowledge economy in Romania (Table 7):

Table 7. Public policy strategies to enhance KE in Romania

\section{Public policies for learning and education}

Governmental programme that will sustain life-long learning in Romanian SMEs by providing financial assistance for employee training (S1.1)

Governmental program that will sustain the development of knowledge repositories at the level of technological clusters, industry associations and other professional organizations by providing financial assistance for hardware acquisition and software development in order to facilitate knowledge transfer (S1.2)

Governmental programme that will sustain the development of professional schools (by providing support to the pupils, and companies hiring them) (S1.3)

\section{Public policies for ICT and Innovation}

Governmental program for the financial support of SME's investments in hardware and software and the development of webpages (S2.2)

Governmental program for the financial support of schools' investments in hardware and educational software and the training of staff for the use of ITC in teaching and learning (S2.2)

Governmental programme for the advancement of the e-government agenda (i.e. the digitalization of public services) and creation of SMEs (S2.3)

Source: Author's own research.

Table 8. Expert final scores and final average scores for strategies to enhance KE in Romania

\begin{tabular}{|c|c|c|c|c|c|c|}
\hline Experts & S1.1 & S1.2 & S1.3 & S2.1 & S2.2 & S2.3 \\
\hline $\begin{array}{c}\text { Expert } \\
\# 1\end{array}$ & 4 & 4 & 5 & 5 & 3 & 5 \\
\hline $\begin{array}{c}\text { Expert } \\
\# 2\end{array}$ & 3 & 4 & 5 & 3 & 5 & 5 \\
\hline $\begin{array}{c}\text { Expert } \\
\# 3\end{array}$ & 5 & 5 & 5 & 4 & 4 & 5 \\
\hline $\begin{array}{c}\text { Expert } \\
\# 4\end{array}$ & 5 & 5 & 4 & 5 & 5 & 5 \\
\hline $\begin{array}{c}\text { Expert } \\
\# 5\end{array}$ & 5 & 4 & 3 & 5 & 5 & 5 \\
\hline $\begin{array}{c}\text { Expert } \\
\# 6\end{array}$ & 4 & 4 & 4 & 4 & 4 & 5 \\
\hline $\begin{array}{c}\text { Expert } \\
\# 7\end{array}$ & 5 & 5 & 4 & 3 & 5 & 5 \\
\hline $\begin{array}{c}\text { Expert } \\
\# 8\end{array}$ & 3 & 3 & 5 & 4 & 5 & 5 \\
\hline $\begin{array}{c}\text { Expert } \\
\# 9\end{array}$ & 5 & 4 & 5 & 5 & 5 & 4 \\
\hline Average & $\mathbf{4 . 3 3 3 3 3 3}$ & $\mathbf{4 . 2 2 2 2 2 2}$ & $\mathbf{4 . 4 4 4 4 4 4}$ & $\mathbf{4 . 2 2 2 2 2 2}$ & $\mathbf{4 . 5 5 5 5 5 6}$ & $\mathbf{4 . 8 8 8 8 8 9}$ \\
\hline
\end{tabular}

Source: Author's own research.

\section{Public policies for education and learning}

1. Governmental programme that will sustain life-long learning in Romanian SMEs by providing financial assistance for employee training

Life-long learning is an important pillar to current knowledge economies and the OECD, the European Union and national states emphasize its contribution to economic development and support its implementation through various instruments and programs (e.g. Horizon 2020). Most of the life-long learning programs are implemented as employee training programs or as professional training programs required in order to remain an active member of a certain profession (e.g. in medical fields) (Dent et al., 2017). However, most SMEs do not have the financial resources necessary for the development of their human resources, which is why they invest less than their larger 
counterparts in life-long learning, although they would enjoy the same or even more benefits than their larger counterparts (Holford et al., 2015). In Romania, almost half of micro-enterprises do not invest in any employee training programs, whereas most medium sized enterprises choose trainings which last between 1 to 5 days per year, and the most common motivation invoked for the lack of investments in training is the financial barrier (Marin, 2015). In 2016, Romania adopted a National strategy for lifelong learning (European Commission, 2016).

2. Governmental program that will sustain the development of knowledge repositories at the level of technological clusters, industry associations and other professional organizations by providing financial assistance for hardware acquisition and software development in order to facilitate knowledge transfer

Knowledge is subject to becoming lost if it is not stored properly. Knowledge repositories are informatic systems which systematize an organization's knowledge resources into easily searchable categories. Moreover, they help connect people with different expertise through discussion forums and private chatrooms. According to previous research, building external knowledge repositories helps raise the competitiveness of regional industries especially in the case of fragmented industries comprised of numerous SMEs (Ernst, 2000, Miron et al., 2010) and that participation in e-knowledge networks is an effective mechanism for organizational learning which leads to increased efficiency and even the creation of new business models (Warketin et al., 2001).

In Romania, there are 43 regional clusters (according to the Romanian Clusters Association) covering various industries including textile, health, maritime, automotive, agriculture. The scant research available on the nature of the activity of these Romanian technology clusters emphasizes the fact that they do not rely on ICT for communication (most of them do not even have websites) and have very few cooperation projects which means that their effect on the competitiveness of their members is small and insignificant (Motoiu et al., 2016; Dan, 2012). Moreover, according to the latest data from the Romanian Ministry for the Business Environment, Commerce and Entrepreneurship (www.antreprenoriat.gov.ro) there are more than 100 professional and trade associations or unions for specific industries such as furniture productions, forestry, tourism, food, energy etc., for specific professions such as engineering, real estate agents, economists etc. and for specific roles such as business women, Turkish entrepreneurs, foreign investors etc. This measure also accounts for innovation since it relates to the ties that can also be created between the academia and industry with respect to potential research and development activities being conducted jointly.

3. Governmental programme that will sustain the development of professional schools (by providing support to the pupils, and companies hiring them)

In Romania, professional schools have suffered tremendous changes: during the communist regime they were highly in demand, after the fall of the communist regime followed by the massive deindustrialisation which brought the decline of these professional schools. In 2009 the professional schools were shut down, and after 2015 the state, with the help of companies, has been trying to revive professional school since the lack of qualified workers in Romania, and has led companies to seek employees in foreign countries, but still the country suffers from an acute lack of professional.

According to the most recent statistical data offered by the Romanian National Institute for Statistics (INSSE, 2015), at country level, today there are only 134 schools 
involved in initial vocational education and training, a very low number if we take into consideration that in 1990 there were 1,306 such schools. Moreover, official data shows that there are only 7 registered professional schools as compared to the 717 that were active in 1992 and only 127 post high school units, compared to 379 in the same year and no foremen schools, when in 1992 there were 210 schools of this type. In 2016 Romania adopted a new vocational and education training strategy (European Commission, 2016).

\section{Public policies for ICT and Innovation}

1. Governmental program for the financial support of SME's investments in hardware and software and the development of webpages

According to Ghilea (2017), 42\% of Romanian SMEs have a web page and this is becoming a major concern since the most efficient advertising medium relates to the online environment. This finding is somewhat contradicting the research conducted by Hadad (2017) that reveals that among 95\% of the respondents are familiar with the term of digitisation. This contradiction could stem from the fact that the master students engaged in the research are part of the Millennials who are very tech-savvy, while the companies' owners belong to a different age cohort. Another important finding was that the managers of these students provided negative answers when asked whether they consider making digital investments, once more aligning with Ghilea's findings. In 2016, only 12 out of 100 Romanian companies advertised by using the Internet therefore placing Romania last at EU level (Ghilea, 2017), whereas at European level $77 \%$ of SMEs have a web page, $45 \%$ use social media for advertising and only $25 \%$ advertise on the Internet. In this context, Romanian companies risk becoming laggard and this is an uncalled for event since the communication infrastructure the country provides is optimal for such kind of undertakings.

In 2014 there were somewhere around the final allocations of European funds on the major intervention line connected to supporting information and communication technology. At the European level ICT and innovation are supported through similar funds and are embedded in the Horizon 2020 agenda (European Commission, 2017), ICT accounts for $4.8 \%$ of the European economy and is expected to increase by $25 \%$ under Horizon 2020 as compared to a previous financial mechanism FP7, "Information and Communication Technologies underpin innovation and competitiveness across private and public sectors and enable scientific progress in all disciplines". A state programme meant to provide financial support for helping SMEs invest in ICT becomes an imperative.

2. Governmental program for the financial support of schools' investments in hardware and educational software and the training of staff for the use of ITC in teaching and learning

Public expenditure on education continues to be very low (3.6\% of GDP) in Romania, and significantly below the European average (European Commission, 2016). Schools in Romania lack equipment (such as computers, videoprojectors) and Internet access - only $66 \%$ of the units that provide education in Romania are connected to the Internet, and the authorities estimate that in 2019-2020 the coverage will reach 100\% (Iosip, 2017). The new strategy adopted in 2015 was aimed at improving the use of ICT in the curricula (European Commission, 2016). 
3. Governmental programme for the advancement of the e-government agenda (i.e. the digitalization of public services) and creation of SMES

The e-government agenda would align to the Digital Single Market Strategy advanced by the European Union which entails digitising and modernising the public administration; ensuring cross-border mobility and engaging digital interactions (European Commission, n.d.). An excellent benchmark and global model in this respect is Estonia which is maybe the only country in the world which has $99 \%$ of its public services available online 24/7 (Estonia, n.d.).

SMEs are regarded as a main source of innovation, growth and competitiveness (David, 2004) and the role of entrepreneurship has changed as a consequence of the transition from the traditional to new economies (Hadad, 2017) and this is why the state has to continuously invest in the backbone of economy - SMEs.

According to the experts' grouping, the EIR pillar would benefit from spillover improvements coming from each of the strategies adopted associated to the other pillars, and therefore they agreed not to address it individually since they did not reach consensus.

Finally, a critical role in developing knowledge economy is played by universities. They create new knowledge and transfer it toward communities, develop generic skills needed in decision-making, and contribute to the long-life and wide-life learning of community members.

\section{Conclusion}

Future research could concentrate on conducting sensitivity analyses to forecast and investigate which measures could impact more the level of knowledge economy. Additionally comparative studies can be performed after the release of new knowledge economy data in December 2017.

The main contribution brought by the hereby paper lies in the managerial, state and academic implications. From the academic standpoint it enhances the theoretical framework of knowledge economy and it benefits higher education institutions, research institutes and other educational and research placements which are knowledge diffusers and transmitters. From the managerial point of view it invites practitioners to rethink the way they conduct their businesses and they generate knowledge, and from the public policy strand it proposes measures for enhancing the development of knowledge economy with a particular focus on Romania.

A limitation of the research is that though the strategies have already been categorised, it is difficult to establish which strategy is going to account for the development of each pillar and the experts agreed that ICT and innovation strategies could be clustered, education and learning can be standalone and EIR would benefit from the others.

\section{Acknowledgement}

The present paper has been financially supported by the Academy of Romanian Scientists, Program No. 11/2017 "Strategies for Implementing Knowledge Economy in Romania".

\section{References}

Bejinaru, R. (2017). Universities in the knowledge economy. Management Dynamics in the Knowledge Economy, Vol. 5, No. 2, pp. 251-271. 
Bolisani, E., and Bratianu, C. (2017). Knowledge strategy planning: an integrated approach to manage uncertainty, turbulence, and dynamics. Journal of Knowledge Management, Vol. 21, No. 2, pp. 233-253.

Bratianu, C. (2011). A new perspective of the intellectual capital dynamics in organizations. In Vallejo-Alonso, B., Rodriguez-Castellanos, A. and ArreguiAyastuy, G. (Eds.). Identifying, measuring, and valuing knowledge-based intangible assets: new perspectives, pp. 1-21. IGI Global, Hershey.

Bratianu, C. (2013). The triple helix of the organizational knowledge. Management Dynamics in the Knowledge Economy, Vol. 1, No.2, pp. 207-220.

Bratianu, C., Agapie, A., Orzea, I. and Agoston, S. (2011). Inter-generational learning dynamics in universities. Electronic Journal of Knowledge Management, Vol. 9, No. 1, pp. 10-18.

Bratianu, C. and Anagnoste, S. (2011). The role of transformational leadership in mergers and acquisitions in emergent economies. Management \& Marketing. Challenges for the Knowledge Society, Vol. 6, No. 2, pp. 319-326.

Bratianu, C., and Bolisani, E. (2015). Knowledge strategy: An integrated approach for managing uncertainty. In Massaro, M. and Garlatti, A. (Eds.). Proceedings of the $16^{\text {th }}$ European Conference on Knowledge Management, University of Udine, Italy, 3-4 September 2015, pp. 169-177. Academic Conferences and International Publishing, Reading.

Bratianu, C. and Vasilache, S. (2010). A factorial analysis of the managerial linear thinking model. International Journal of Innovation and Learning, Vol.8, No. 4, pp. 393-407.

Brinkley, I. (2006). Defining the knowledge economy, Knowledge economy programme report, DTI Competitiveness White Paper, The Work Foundation, http://www.theworkfoundation.com/assets/docs/publications/65_defining\%2 0knowledge\%20economy.pdf.

Chen, D. and Dahlman, C.J. (2005). The Knowledge Economy, the KAM Methodology and World Bank Operations, World Bank Institute, Working Paper 37256, http://papers.ssrn.com/sol3/papers.cfm?abstract_id=841625.

Dan, M.C. (2012). Innovative clusters: A solution for the economic development of Romania. Theoretical and Applied Economics, Vol. 21, No. 9, pp. 5-16.

David B.A. (2004). Sustaining Innovation and Growth: Public Policy Support for Entrepreneurship, Industry and Innovation, Vol. 11, No. 3, pp. 167-191.

Dent, J., Harden, R.M., and Hunt, D. (2017). A practical guide for medical teachers. Elsevier Health Sciences.

Đonlagić, S., Fazlić, S., and Nuhanović, A. (2015). Introducing a framework for knowledge economy development in transition countries: The case of Bosnia and Hercegovina. Ekonomski Vjesnik/Econviews: Review of contemporary business, entrepreneurship and economic issues, Vol. 28, No. 1, pp. 257-266.

Ernst, D. (2000). Inter-organizational knowledge outsourcing: What permits small Taiwanese firms to compete in the computer industry?. East-West Center Working Papers. East-West Center, Hawaii.

Estonia (n.d.). E-governance, Retrieved from: https://e-estonia.com/solutions/egovernance/.

European Commission (n.d.). European eGovernment Action Plan 2016-2020, Retrieved from https://ec.europa.eu/digital-single-market/en/european-egovernmentaction-plan-2016-2020.

European Commission (2004). Manufacture. A Vision for 2020, Belgium. 
European Commission (2016). Education and Training Monitor 2016 Romania, Retrieved from https://ec.europa.eu/education/sites/education/files/monitor 2016-ro_en.pdf.

European Commission (2017). ICT Research and Innovation, Retrieved from: https://ec.europa.eu/programmes/horizon2020/en/area/ict-researchinnovation.

Fonseca, L. M., \& Domingues, J. P. (2017, July). Listen to ISO 9001: 2015 for organizational competitiveness: Correlation between change management and improvement. In Proceedings of the International Conference on Business Excellence (Vol. 11, No. 1, pp. 916-926). De Gruyter Open.

Franklin, K.K., \& Hart, J.K. (2007). Idea generation and exploration: Benefits and limitations of the policy Delphi research method. Innovation in Higher Education, Vol. 31, No. 4, pp. 237-246.

Freedom House (2001). Report on Romania, Retrieved from: https://freedomhouse.org/report/fr eedom-world/2001/romania.

Fucec, A.A. (2015). Romania And The Knowledge Economies In The European Union: Status, Progress And Effects. In Proceedings of the INTERNATIONAL MANAGEMENT CONFERENCE (Vol. 9, No. 1, pp. 598-605). Faculty of Management, Academy of Economic Studies, Bucharest, Romania.

Ghilea, R. (2017). Alarming marketing statistics. Only 12\% of Romanian companies advertised online. Retrieved online: http://www.adplayers.ro/articol/Business6/Statistici-de-marketing-ingrijoratoare-Doar-12-din-firmele-romanesti-si-aufacut-publicitate-online-5315.html.

Ghinea, V.M. and Bratianu, C. (2012). Organizational culture modelling. Management \& Marketing. Challenges for the Knowledge Society, Vol.7, No. 2, pp. 257-276.

Gordon, T.J. (n.d.) The Delphi method, The millennium Project. Retrieved from: millennium-project.org/FRMv3_0/04-Delphi.pdf

Hadad, S. (2015). Analytic hierarchy process analysis for choosing a corporate social entrepreneurship strategy. Management \& Marketing, Vol. 10, No. 3, pp. 185-207.

Hadad, S. (2017). "Knowledge economy: Characteristics and dimensions", Management Dynamics in the Knowledge Economy, Vol.5, No. 2, pp. 203-225.

Hadad, S. (2017). Business Digitization in the Romanian Economy, in the Proceedings of Strategica. Shift. Major challenges of today`s economy.

Herciu, M., Ogrean, C. (2011). Interrelations between economic freedom, knowledge economy and global competitiveness - comparative analysis Romania and EU average, Studies in Business and Economics, Vol. 6, No. 2, pp. 46-59.

Holford, J., Cort, P., Larson, A., Melo, S., Studena, I., and Tota, P.M. (2015). Public policies support lifelong learning among company employees. LLLightinEurope Research Consortium, Friedrichsafen.

Hsu, C.C., and Sandford, B.A. (2007). The Delphi technique: making sense of consensus. Practical assessment, research \& evaluation, Vol. 12, No. 10, pp. 1-8.

INSSE. (2017), Professional schools, Retrieved from www.insse.ro.

Iosip, F. (2017). In two years, all school units will have Internet and surveillance cameras, Retrieved from: http://adevarul.ro/educatie/scoala/liviu-pop-promitedoi-ani-unitatile-scolare-vor-internet-supraveghere-video-1_597b2cb15ab6550 cb891c31e/index.html.

Lang, T. (1994). An overview of four futures methodologies. Retrieved from: www. soc.hawaii.edu/ future/j7/LANG.html. 
Marin, I. (2015). Human resources insights regarding Romanian SMEs. Proceedings of the $9^{\text {th }}$ Intenrational Management Conference "Management and Innovation for Competitive Advantage", November 5-6, Bucharest, Romania, pp. 606-613.

Miron, D., Dima, A.M. and Vasilache, S. (2010), Models of The Intra-Regional Trade Influence On Economic Sustainable Development In Romania, Amfiteatru Economic, Vol. 12, No. 27, pp. 27 -35.

Motoiu, E., Pavel, O.A., and Lakatos, E.S. (2016). A brief quantitative analysis of clusters from the creative industry in Romania. Review of Applied Socio-Economic Research, Vol. 11, No. 2, pp. 57-66.

Murry, J.W., and Hammons, J.O. (1995). Delphi: A versatile methodology for conduction qualitative research. The Review of Higher Education, Vol. 18, No. 4, pp. 423-436.

Nonaka, I. and Takeuchi, H. (1995). The knowledge-creating company: How Japanese companies create the dynamics of innovation. Oxford University Press, Oxford.

OECD (1996). The knowledge based economy. Retrieved from https://www.oecd.org/sti/sci-tech/1913021.pdf.

Ogrean, C., Herciu, M., and Belascu, L. (2010). From technological readiness to business sophistication through ICT applications, Research in Business and Economics Journal, Vol. 2, No.1, pp. -.

Popa, A.E. (2013). Premises of knowledge based economy in Romania, Proceedings of the International Management Conference, Faculty of Management, Academy of Economic Studies, Bucharest, Romania, Vol. 7, No. 1, pp. 565-573.

Saaty, T. L. (2008). Decision making with the analytic hierarchy process. International journal of services sciences, Vol. 1, No. 1, pp. 83-98.

Skrodzka, I. (2016). Knowledge-Based Economy in the European Union-Cross-country Analysis. STATISTICS, Vol. 17, No. 2, pp. 281-294.

Veugelers, R. and Mrak, M. (2009). The Knowledge Economy and Catching-up Member States of the European Union, Report prepared for Commissioner's Potocnik's Expert Group, "Knowledge for Growth", May, http://ec.europa.eu/invest-inresearch/pdf/download_en/kfg_report_no5.pdf.

Waretin, M., Sugumaran, V., and Bapna, R. (2001). E-knowledge networks for interorganizational collaborative e-business. Logistics Information Management, Vol. 14 , No. $1 / 2$, pp. $149-162$.

Whitaker, R. (2007). Validation examples of the analytic hierarchy process and analytic network process. Mathematical and Computer Modelling, Vol. 46, No. 7, pp. 840859.

World Bank $(2009,2012)$. Measuring Knowledge in the World's economies, Knowledge for Development, Retrieved from www.worldbank.org/wbi/k4d.

World Bank, www.worldbank.org. 